\title{
KEBIJAKAN PENDIDIKAN DI INDONESIA: EVALUASI TERHADAP RUMUSAN KEBIJAKAN KURIKULUM BIDANG PENDIDIKAN TINGGI
}

\author{
Binsar A. Hutabarat \\ Reformed Center for Religion and Society
}

\begin{abstract}
This article entitled, "The Policy of Education in Indonesia: An Evaluation towards The Formula of Curriculum Policy for Higher Education" focuses on the study of the formulation of curriculum policy which refers to the framework of national qualification in Indonesia. This research uses qualitative method: the data was gathered through an interview, questionnaire distribution, and observation on three tertiary institutions in Indonesia, also secondary data in the form of selected books. This research finds that a curriculum policy which refers to the framework of national qualification in Indonesia is an elite product and weak in terms of socialization, and the consequence of this policy's application is not as expected.
\end{abstract}

KEYWORDS: policy of education, evaluation of policy, higher education curriculum

ABSTRAK: Artikel yang berjudul "Kebijakan Pendidikan di Indonesia: Evaluasi terhadap Rumusan Kebijakan Kurikulum Bidang Pendidikan Tinggi" ini fokus pada kajian perumusan kebijakan kurikulum mengacu pada kerangka kualifikasi nasional Indonesia. Penelitian ini menggunakan metode kualitatif, data dikumpulkan melalui wawancara, penyebaran kuesioner, observasi pada tiga perguruan tinggi di Indonesia, serta data-data sekunder berupa pustaka terpilih. Temuan penelitian ini adalah kebijakan kurikulum mengacu pada kerangka kualifikasi nasional Indonesia merupakan produk elite dan lemah dalam sosialisasi, akibatnya pelaksanaan kebijakan tersebut tidak sesuai dengan yang diharapkan. 
KATA-KATA KUNCI: kebijakan pendidikan, evaluasi kebijakan, pendidikan tinggi, kurikulum Pendidikan tinggi.

\section{Pendahuluan}

Kebijakan pendidikan nasional Indonesia sesungguhnya menempati posisi yang sentral bagi usaha memajukan bangsa Indonesia. Apabila pemerintah Indonesia gagal membuat kebijakan yang unggul dalam bidang pendidikan, maka taruhannya adalah kerusakan dan kehancuran kehidupan bangsa Indonesia. Kebijakan pendidikan yang buruk akan berdampak panjang. Indonesia hanya bisa menjadi bangsa yang unggul jika kebijakan yang dihasilkan adalah kebijakan-kebijakan yang unggul dan tentu saja dapat diimplementasikan. ${ }^{1}$

Pendidikan tinggi Indonesia memasuki sebuah dekade baru setelah pemerintah Indonesia meratifikasi beberapa perjanjian dan komitmen global (AFTA, WTO, GATTS). Pemberlakuan berbagai kesepakatan internasional nyata dalam hal seperti diberlakukannya berbagai macam parameter kualitas untuk menstandarkan kualitas dan mutu perguruan tinggi berikut lulusannya. Tahun 2013, ASEAN Economic Community mempersiapkan AFTA (ASEAN Free Trade Association Area) 2012. Sedang WTO (World Trade Organization) merupakan satu organisasi internasional yang berperan untuk mengatur transaksi perdagangan yang dilakukan oleh negara-negara anggotanya terbentuk tahun 1995. WTO sebenarnya sudah memiliki dasarnya pada General Agreement on Tariffs and Trade (GATT) pada tahun 1947. WTO mengatur beberapa hal mengenai perdagangan barang (goods), jasa (service) dan kekayaan intelektual (property rights). Dengan kehadiran organisasi-organisasi internasional itu, maka kesepakatan dan kesepahaman antarnegara-negara di ASEAN mulai ditetapkan. Peta pengembangan (road map) mobilitas bebas tenaga kerja profesional

1 Riant Nugroho, Public Policy (Jakarta: IKAPI, 2009), 29. 
antarnegara di ASEAN mulai dibentangkan. ${ }^{2}$ (Sailah, 2014).

Ancaman pendidikan era global untuk pendidikan di Indonesia semakin terasa ketika diperhadapkan dengan mutu pendidikan di Indonesia saat ini, khususnya pendidikan tinggi. Rendahnya kualitas pendidikan tinggi di Indonesia bukan berarti bahwa pendidikan di Indonesia tidak mengalami pertumbuhan sama sekali, namun arus globalisasi yang membuka sekat-sekat antarnegara mengakibatkan persaingan antarnegara menjadi jauh lebih terbuka, karena itu harus diakui, "mutu pendidikan di Indonesi secara umum memiliki standar yang lebih rendah dibandingkan negara-negara lain, khususnya terhadap negara-negara maju. ${ }^{3}$

Kondisi tersebut membuat pemerintah Indonesia harus menyusun strategi pengembangan pendidikan Indonesia yang relevan dalam menyongsong era globalisasi. Karena itu, perubahan mendasar pada bidang pendidikan tinggi di Indonesia tak dapat dihindari. Pendidikan tinggi di Indonesia pada era global kemudian diarahkan menjadi lembaga pembelajaran dan sumber pengetahuan yang memiliki interaksi dengan perubahan pasaran kerja, di samping sebagai tempat pengembangan budaya dan pembelajaran terbuka untuk masyarakat, maupun wahana kerjasama internasional. ${ }^{4}$

Kondisi persaingan global dalam area pendidikan kemudian secara khusus direspon oleh Kementerian Pendidikan Nasional dengan meluncurkan sebuah booklet tentang Kerangka Kualifikasi Nasional Indonesia (KKNI) yang berisi tentang implikasi dan strategi implementasi KKNI pada tahun 2010/2011. Hasil perumusan kebijakan KKNI bidang pendidikan tinggi itu kemudian dituangkan dalam Peraturan Presiden (Perpres) Nomor 8 tentang Kerangka Kualifikasi

\footnotetext{
2 Illah Sailah, dkk., Buku Panduan Kurikulum Pendidikan Tinggi (Jakarta: Kementerian Pendidikan dan Kebudayaan, 2014), 3.

3 H.A.R. Tilaar, Standardisasi Pendidikan Nasional (Jakarta: Rineka Cipta, 2006), 10.

4 Tresna Dermawan Kunaefi, dkk. Buku Panduan Pengembangan Kurikulum Berbasis Kompetensi, Pendidikan Tinggi (Jakarta: Direktorat Akademik, Direktorat Jenderal Pendidikan Tinggi, 2008), 9.
} 
Nasional Indonesia (KKNI) tahun 2012. Kebijakan penerapan KKNI di perguruan tinggi ini kemudian mendapatkan landasan hukum yang kuat pada UU Pendidikan Tinggi No.12 Tahun 2012 tentang Pendidikan Tinggi.

Untuk melaksanakan kebijakan KKNI yang ditetapkan dalam Peraturan Presiden 2012, Menteri Pendidikan dan Kebudayaan menetapkan Peraturan Menteri Pendidikan dan Kebudayaan Republik Indonesia Nomor 73 Tahun 2013 tentang Penerapan Kerangka Kualifikasi Nasional Indonesia Bidang Pendidikan Tinggi. Kebijakan penerapan KKNI di perguruan tinggi itu bertujuan untuk meningkatkan kualitas tenaga kerja Indonesia, sebagaimana juga menjadi tujuan penetapan KKNI pada sektor pelatihan kerja nasional yang ditetapkan dalam Peraturan Pemerintah tahun 2006 tentang Sistem Pelatihan Kerja Nasional. Penerapan KKNI bidang pendidikan tinggi dan sektor pelatihan kerja akan menjadi peta jalan peningkatan kualitas tenaga kerja Indonesia.

Penetapan KKNI sebagai kerangka penjenjangan kualifikasi kompetensi kerja dalam pelatihan kerja ditetapkan juga sebagai acuan kualifikasi kemampuan lulusan perguruan tinggi. Tujuannya adalah agar terdapat integrasi antara bidang pendidikan dan bidang pelatihan kerja serta pengalaman kerja dalam rangka pemberian pengakuan kompetensi kerja sesuai dengan struktur pekerjaan di berbagai sektor.

Menurut penelitian awal, kebijakan penerapan KKNI di bidang pendidikan tinggi ini telah menimbulkan kontroversi. Karena kebijakan KKNI oleh sebagian dosen dianggap mereduksi visi, misi, perguruan tinggi menjadi sekadar institusi pemasok "tenaga kerja", untuk kebutuhan industri. Pada sisi lain, sebagian dosen setuju dengan kebijakan penerapan KKNI karena selama ini belum ada acuan kualifikasi untuk lulusan pendidikan formal. Mereka yang setuju terhadap kebijakan KKNI berpendapat, sebagaimana pendidikan kerja telah menggunakan KKNI sebagai acuan kualifikasi lulusan pelatihan kerja, maka pendidikan tinggi juga harus mempunyai acuan yang sama 
agar lulusan perguruan tinggi dapat diterima pada dunia kerja, terlebih lagi dengan persaingan global pada bidang pendidikan tinggi.

Terkait dengan kebijakan KKNI tersebut hingga saat ini belum pernah dilakukan evaluasi terhadap kebijakan KKNI bidang pendidikan tinggi. Karena itu, perlu dilakukan penelitian evaluasi kebijakan KKNI untuk mengetahui bagaimanakah struktur dan rumusan kebijakan KKNI serta kondisi perguruan tinggi sebagai sasaran kebijakan tersebut. Apakah kebijakan KKNI merupakan jawaban terhadap kebutuhan perguruan tinggi dalam menghadapi ancaman global di bidang pendidikan, dan apakah kebijakan dapat diterima perguruan tinggi sebagai sebuah alternatif kebijakan untuk meningkatkan kualitas perguruan tinmggi di Indonesia. Penelitian kebijakan KKNI ini ditekankan untuk mendapatkan informasi tentang bagaimanakah perumusan kebijakan tersebut dan bagaimanakah isi kebijakan KKNI bidang pendidikan tinggi. Penelitian ini lebih kepada evaluasi rumusan dari kebijakan KKNI. Apakah perumusan kebijakan KKNI itu telah melalui tahapan-tahapan yang seharusnya dilakukan dalam perumusan kebijakan dalam sistem pemerintahan yang demokratis.

Kerangka Kualifikasi Nasional (National Qualification Framework) tidak hanya ada di Indonesia, tetapi juga pada banyak negara di dunia. Kerangka kualifikasi nasional merupakan fenomena global. Sebanyak 70 negara di seluruh dunia saat ini sedang mengembangkan kerangka kualifikasi nasional, baik itu negara-negara yang maju dalam industri dan perekonomiannya, negara-negara anggota Uni Eropa, dan juga negara-negara berkembang di Asia dan di Afrika. Kerangka kualifikasi nasional ini merupakan isu besar terkait dengan elemen pendidikan dan ketenagakerjaan. Mengenai Kerangka Kualifikasi Nasional, Gavin Heron \& Pam Green Lister menjelaskan, bahwa "kerangka kualifikasi nasional dimaksudkan untuk memberikan pedoman cara mengkualifikasikan level-level pendidikan yang berbeda dan membandingkannya baik 
secara nasional maupun internasional dengan cara yang memungkinkan." 5

Secara umum, kerangka kualifikasi dapat didefinisikan sebagai "deskripsi sistematis kualifikasi suatu sistem pendidikan."6 Mengikuti pendekatan ini, adalah mungkin untuk mengklaim bahwa setiap negara memiliki kerangka kualifikasi nasional. ${ }^{7}$ Kerangka Kualifikasi Nasional telah dikembangkan dan digunakan di seluruh dunia. Di Eropa, bahkan ada 'meta' kerangka, Eropean Qualification Framework (EQF) yang mencoba untuk menyelaraskan dan mengkonsolidasikan beberapa kerangka kerja nasional ke satu titik acuan. ${ }^{8}$

\section{Metodologi Penelitian}

Metode yang digunakan dalam penelitian ini adalah metode penelitian kualitatif. Metode kualitatif ini digunakan dengan alasan karena masalah-masalah penelitian perlu digali untuk mendapatkan sebuah pengertian yang mendalam (Creswell, 2007). Lebih jauh Creswell menjelaskan: "This exploration is needed, in turn, because of a need to study a group of population, identify variable that can then be measured, or hear silenced voices." $"$

Data kualitatif bisa berupa dokumen atau catatan dari interview, catatan observasi lapangan, hasil kuesioner, hasil foto, video, email dan hasil pertemuan dengan responden. ${ }^{10}$ Data kualitatif ini memungkinkan pembaca mendapatkan pemahaman yang melampaui angka-angka dan

5 Gavin Heron \& Pam Green Lister, "Influence of National Qualifications Frameworks in Conceptualizing Feedback to Students" Social Work Education Vol. 33, No. 4 (2014), 420-34.

6 Ibid.

7 Irma Spûdytë, Saulius Vengris, Mindaugas Misiûnas, "Qualifications of Higher Education in the National Qualifications Framework" Vocational Education: Research and Reality (2006), 23.

8 Scott Fernie, Nick Pilcher \& Karen L. Smith, “The Scottish Credit and Qualifications Framework: What's Academic Practice Got to do With It?" European Journal of Education (Vol. 49, No. 2, 2013), 233.

9 John W. Creswell, Educational Research (Boston: Pearson. 2012), 16-8.

10 Patricia J. Rogers, Delwyn Goodrick, "Qualitative Data Analysis” dalam Joseph S. Wholey, et. al., Hand Book of Program Evaluation (San Francisco: Jossey-Bass, 2010), 429. 
statistik inferensi.11 Teknik pengumpulan data kualitatif dilakukan dengan menggunakan teknik kondisi yang alami, sumber data primer, dan teknik observasi, wawancara mendalam, dan dokumentasi. ${ }^{12}$ Teknik pengumpulan data yang digunakan dalam penelitian evaluasi ini adalah wawancara (interview) untuk mengetahui hal-hal yang lebih mendalam dari responden. ${ }^{13}$ Teknik yang digunakan adalah wawancara tidak terstruktur untuk mendapatkan informasi yang lebih mendalam.

Teknik analisis data kualitatif secara tipikal mengikuti langkahlangkah pengumpulan data yang dikumpulkan ke dalam kategorikategori informasi yang disusun. Teknik pengumpulan data secara kualitatif menggunakan teknik triangulasi artinya pengumpulan data dilakukan secara terus-menerus sampai mendapatkan data jenuh. ${ }^{14}$

Selanjutnya, mengenai teknik analisis data kualitatif ini dilakukan dengan menyusun data yang telah dikumpulkan melalui wawancara, catatan lapangan, dan bahan-bahan lain secara sitematis agar temuan tersebut dapat menjadi bahan informasi. Analisis data dilakukan dengan mengorganisir data berupa informasi itu, menjabarkannya dalam unitunit dengan melakukan sintesis, kemudian menyusun dalam pola, memilih yang penting untuk dipelajari, dan kemudian dibuat kesimpulan. ${ }^{15}$

\section{Evaluasi Struktur dan Rumusan Kebijakan KKNI}

a. Pemahaman dosen tentang isi kebijakan KKNI

Informasi kebijakan KKNI telah disampaikan kepada pelaksana kebijakan penerapan KKNI di perguruan tinggi, dalam hal ini adalah dosen dan kepala program studi di perguruan tinggi. Tujuan sosialisasi

\footnotetext{
$11 \quad$ Ibid.

12 M. Djunaidi Ghony dan Fauzan Almanshur, Metodologi Penelitian Kualitatif (Yogyakarta: Ar-Ruzz Media, 2012), 164.

13 Sugiyono, Metode Penelitian Pendidikan (Bandung: Alfa Beta, 2012), 194.

14 Ibid.

15 Ibid.
} 
isi kebijakan KKNI kepada para pelaksana kebijakan adalah agar para pelaksana kebijakan, termasuk sasaran kebijakan yakni pengelola perguruan tinggi termasuk antara lain kepala program studi dan dosen dapat mengetahui, memahami apa yang menjadi isi, tujuan, arah, dan kelompok sasaran kebijakan. Harapan penyelenggaraan sosialisasi itu sesungguhnya adalah agar para pelaksana kebijakan dapat mempersiapkan diri dengan benar apa yang harus dipersiapkan, dan apa yang harus dilakukan untuk melaksanakan kebijakan KKNI tersebut, sehingga apa yang menjadi tujuan dan sasaran kebijakan KKNI dapat dicapai sesuai dengan apa yang diharapkan. Namun, data wawancara dan kuesioner menjelaskan, bahwa belum semua dosen memahami rumusan kebijakan KKNI tersebut, karena belum semua dosen mendapat kesempatan untuk mengikuti sosialisasi berisi pengenalan umum mengenai kebijakan KKNI, itulah sebabnya ditemukan terdapat dosen sebagai pelaksana kebijakan penerapan KKNI yang belum memiliki kompetensi yang cukup untuk menerapkan KKNI di perguruan tinggi.

Menurut data wawancara diketahui, bahwa sebagian dosen yang telah mengikuti sosialisasi tentang KKNI masih terdapat yang belum juga memahami dengan baik apa yang menjadi isi dari KKNI, menurut data, sosialisasi KKNI perlu berulang-ulang dan bertingkat. Dosen yang hanya mengikuti sosialisasi secara umum tanpa tindak lanjut pada pemahaman yang lebih mendalam sulit untuk memahami kebijakan KKNI dengan baik. Karena itu ditemukan bahwa dosen yang hanya mengikuti sosialisasi KKNI secara umum, dalam bentuk seminar yang dihadiri sejumlah besar dosen, dan kegiatan tersebut tidak rutin, atau relatif jarang, belum memahami dengan baik isi rumusan kebijakan KKNI tersebut. Itulah sebabnya ditemukan variasi pemahaman dosen terhadap kebijakan KKNI. Bahkan,ada dosen yang mengungkapkan bahwa isi kebijakan KKNI itu masih menjadi sesuatu yang asing meski penetapan kebijakan KKNI itu telah berlangsung lama, yakni sejak tahun 2012.

Variasi pemahaman dosen di perguruan tinggi terhadap KKNI 
dapat diketahui dari beberapa pandangan dosen dalam wawancara langsung. Sebagian responden mengatakan, tidak ada perubahan signifikan dengan kebijakan KKNI di bidang pendidikan tinggi, "KKNI melihat ekuivalensi lulusan perguruan tinggi dengan dunia kerja, jadi perubahan kurikulumnya tidak signifikan."16 Selanjutnya seorang responden menjelaskan demikian, "dalam konsorsium matematika, mata kuliah yang ditetapkan juga tetap sama. Baik kurikulum berbasis kompetensi dan kurikulum yang mengacu KKNI, keduanya memiliki mata kuliah yang sama, hanya cara pandangnya saja yang berbeda." 17

Seorang responden lain dalam sebuah wawancara berkomentar, "KKNI itu bagus untuk melakukan kontrol relevansi tamatan pendidikan tinggi dan dunia kerja, tapi tidak harus diberlakukan untuk semua prodi."18 Lebih lanjut responden tersebut berujar, Karena tidak semua orang yang kuliah itu ingin bekerja."19 Selanjutnya dijelaskan, "kalau untuk pekerjaan di bidang keprofesian saya relatif setuju, karena itu didasarkan kualifikasi dan kompetensi yang terukur. Tapi, untuk bidang keilmuan, penerapan KKNI itu agak sulit mengukurnya. Responden tersebut juga berkomentar. Untuk mengukur apakah lulusan perguruan tinggi di Indonesia memiliki kedekatan dengan dunia kerja sesungguhnya juga tidak mudah, untuk prodi yang spesifik memang agak mudah melacaknya, demikian ujar seorang narasumber." 20 Responden tersebut lebih lanjut menjelaskan, untuk prodi sosial, termasuk dalam hal ini prodi non-guru, filsafat, serta ilmu-ilmu dasar lainnya, di mana lulusannya tidak spesifik, khususnya pada tingkat pasca sarjana. jika ukuran kualitas perguruan tinggi dilihat dari kedekatan luaran perguruan tinggi dengan dunia kerja untuk prodiprodi tertentu menurutnya tidak tepat. ${ }^{21}$

\footnotetext{
Data wawancara.

Data wawancara.

Data wawancara.

Data wawancara.

Data wawancara.

21 Data wawancara.
} 
Menanggapi adanya jurang yang cukup tinggi antara lulusan perguruan tinggi dengan dunia kerja yang adalah fakta itu, seorang dosen mengungkapkan, bahwa itu terjadi bukan hanya karena luaran perguruan tinggi tidak sesuai dengan dunia kerja, tapi bisa juga karena lapangan kerja yang sesuai dengan bidang pendidikan lulusan tersebut tidak menjanjikan bagi kesejahteraan hidup pekerja. Tidak sedikit tamatan perguruan tinggi strata satu mengambil prodi S2 yang tidak linier dengan prodi yang telah diambil sebelumnya. Dan alasan perpindahan prodi itu beragam, salah satunya menurut seorang responden membandingkan dengan pendidikan di luar negeri berujar, bahwa perpindahan program studi yang tidak linier dari mahasiswa yang melanjut ke S2 disebabkan karena pada tahun pertama di perguruan tinggi seorang calon mahasiswa sudah harus menentukan program studi yang akan diambilnya, berbeda dengan pendidikan di Amerika Serikat, misalnya yang mengijinkan mahasiswa setelah tiga tahun kuliah baru diijinkan mengambil program studi yang akan ditekuninya. ${ }^{22}$

b. Pemahaman dosen tentang landasan hukum KKNI

Pelaksanaan KKNI sangat dipengaruhi oleh pemahaman dosen tentang landasan hukum KKNI. Apabila dosen memahami bahwa KKNI memiliki landasan perundang-undangan yang jelas, maka dosen dan pengelola perguruan tinggi memiliki komitmen untuk menerapkan KKNI di perguruan tinggi. Namun, sebagaimana telah dijelaskan, temuan menunjukkan bahwa sebagian dosen belum memahami isi kebijakan KKNI karena sosialisasi yang belum menyertakan semua dosen perguruan tinggi. Temuan data menjelaskan bahwa meskipun belum semua dosen memahami dengan baik tentang rumusan kebijakan KKNI , namun pada umumnya dosen mengakui bahwa landasan hukum kebijakan penerapan KKNI itu memiliki landasan yang kuat dalam perundang-undangan RI. Alasannya adalah karena memang kebijakan

22 Data wawancara. 
KKNI itu dituangkan dalam Peraturan Presiden Nomor 8 Tahun 2012. Kebijakan penerapan KKNI itu juga ditetapkan dalam Undang-undang Pendidikan Tinggi Tahun 2012, dan kemudian juga dalam Peraturan Menristek Dikti 2015.

Secara struktur, kebijakan KKNI itu telah memenuhi syarat sebagai sebuah kebijakan, karena telah ditetapkan dalam perundang-undangan, dengan demikian maka kebijakan penerapan KKNI itu memiliki landasan yang kuat. Meskipun demikian, ada sebagian dosen mengatakan bahwa ada perguruan tinggi yang menerapkan KKNI bukan karena memahami bahwa kebijakan KKNI itu memiliki landasan yang kuat, tetapi karena perguruan tinggi tersebut memang tidak memiliki alasan untuk menolaknya, lebih lanjut dijelaskan karena KKNI adalah sebuah kebijakan pemerintah menurutnya, maka penerapannya di perguruan tinggi harus dilakukan, dengan keyakinan bahwa kebijakan itu pasti bermanfaat bagi perguruan tinggi yang menjadi sasaran kebijakan.

c. Pemahaman dosen tentang manfaat KKNI

Pengetahuan mengenai manfaat penerapan kebijakan KKNI bidang pendidikan tinggi berpengaruh terhadap komitmen dosen dan perguruan tinggi untuk melaksanakan KKNI di perguruan tinggi. Data yang didapat melalui wawancara adalah dosen dan perguruan tinggi masih belum semua memahami tentang isi kebijakan KKNI. Kurangnya pemahaman dosen tersebut tentang KKNI maka secara bersamaan juga belum semua dosen memahami manfaat tentang penerapan KKNI. Data melalui kuesioner menjelaskan bahwa dosen umumnya setuju bahwa penerapan KKNI dibutuhkan karena manfaat yang besar untuk perguruan tinggi. Hal ini terlihat pertama-tama pada jawaban butir tentang, "Kerangka kualifikasi nasional di bidang pendidikan dibutuhkan di setiap negara untuk menghadirkan pendidikan yang bermutu. Pada umumnya semua dosen menyatakan setuju. Data itu juga sesuai dengan pengumpulan data tentang pilihan butir, "Kerangka Kualifikasi Nasional Indonesia (KKNI) sudah sangat mendesak untuk 
perbaikan mutu pendidikan tinggi, dan pada umumnya semua dosen memilih setuju. Jadi, berdasarkan data wawancara dan kuesioner dosen di perguruan tinggi setuju untuk kebijakan penerapan KKNI.

Dari hasil pengumpulan data melalui kuesioner terlihat bahwa pada umumnya dosen meyakini manfaat penerapan KKNI. Itulah sebabnya umumnya perguruan tinggi telah berusaha menerapkan kebijakan KKNI. Pada sisi lain, pemahaman dosen terhadap KKNI berdasarkan wawancara masih kurang dan sangat bervariasi. Jadi, keyakinan dosen yang tinggi terhadap penerapan KKNI di perguruan tinggi lebih kepada pemahaman seperti apa yang dikatakan beberapa dosen, bahwa karena KKNI adalah kebijakan pemerintah, maka KKNI harus diterapkan di perguruan tinggi. Keyakinan itu sejalan dengan kekhawatiran seorang dosen yang mengatakan harapannya, agar kebijakan penerapan KKNI di perguruan tinggi tidak seperti kebijakan lain yang berubah setiap kali terjadi pergantian menteri.

Berdasarkan temuan yang telah dipaparkan di atas jelaslah bahwa pemahaman dosen tentang struktur kebijakan KKNI, landasan kebijakan KKNI, tujuan dan manfaat dari kebijakan tersebut belum dipahami semua dosen di perguruan tinggi.

Data wawancara mengenai kondisi lingkungan eksternal kebijakan perguruan tinggi di Indonesia terkait dengan era global menjelaskan bahwa perguruan tinggi di Indonesia sedang menghadapi tantangan yang tidak mudah untuk bertahan dalam persaingan global. Tuntutan untuk dapat berkompetensi dengan pendidikan di negara-negara maju menjadi lebih terbuka. Kondisi persaingan global itu menurut responden menjadi salah satu pendorong mengapa perguruan tinggi berusaha menerapkan KKNI dalam kondisi keterbatasan pemahaman atas kebijakan tersebut. Data ini didukung oleh hasil kuesioner terhadap dosen perguruan tinggi dengan butir pernyataan, "perguruan tinggi di Indonesia sedang menghadapi tantangan era global, hampir semua dosen sepakat bahwa kondisi perguruan tinggi di Indonesia sedang menghadapi persaingan global. Jadi artinya, pada umumnya dosen 
perguruan tinggi sepakat bahwa Indonesia sedang menghadapi tantangan era global dengan diberlakukannya standar internasional di bidang pendidikan pada setiap negara. Dengan diberlakukannya standar internasional di bidang pendidikan itu di banyak negara, maka responden setuju bahwa KKNI bidang pendidikan dibutuhkan di setiap negara untuk menghadirkan pendidikan yang bermutu. Keyakinan yang tinggi dari penerapan kebijakan KKNI tersebut lebih didorong oleh kesadaran untuk merespon ancaman terhadap pendidikan pada era global, bukan karena pemahaman yang baik terhadap rumusan kebijakan KKNI. Data tersebut di atas sesuai dengan data hasil kuesioner dengan butir pernyataan, "perguruan tinggi di Indonesia sedang menghadapi tantangan era global," hampir semua dosen sepakat tentang kondisi itu.

Berdasarkan temuan tentang pemahaman konteks lingkungan kebijakan penerapan KKNI diketahui bahwa pemerintah belum dapat memanfaatkan ancaman global dalam bidang pendidikan tinggi untuk mempengaruhi pendidikan tinggi sebagai sasaran kebijakan untuk dapat menjadikan kebijakan KKNI sebagai alternatif kebijakan untuk menolong perguruan tinggi di Indonesia menghadapi persaingan global. Itulah sebabnya, belum semua pendidikan tinggi mengembangkan kurikulum mengacu pada KKNI.

\section{Pembahasan}

Kebijakan unggul pastilah dapat dilaksanakan dengan baik. Sebaliknya kebijakan yang tidak dirumuskan dengan baik maka dalam pelaksanaan akan mengalami banyak hambatan, dan tujuan yang telah ditetapkan dalam kebijakan tersebut tidak dapat tercapai. ${ }^{23}$ Hal ini juga sejalan dengan apa yang dikatakan Parsons, pembuatan kebijakan tidak mencapai tujuan sering kali disebabkan karena kebijakan itu tidak

23 Joko Widodo, Analisis Kebijakan Publik (Malang: Bayu Media, 2006), 85. 
didefinisikan dengan baik. ${ }^{24}$

Berdasarkan apa yang dikatakan Parsons dan Joko Widodo jelaslah bahwa kebijakan KKNI yang telah diterapkan di perguruan tinggi, dan jika tidak memenuhi tujuan dari yang diharapkan, bisa menunjukkan bahwa ada yang salah dalam perumusan kebijakan KKNI yang secara khusus dituangkan dalam Peraturan Presiden Republik Indonesia Nomor 8 Tahun 2012 tentang Kerangka Kualifikasi Nasional.

Model yang digunakan dalam perumusan kebijakan KKNI adalah model campuran, yakni antara "model elite" 25 , "model rasional" 26 dan "model publik"27. Model elite lebih dominan dibandingkan kedua model lain. Dengan demikian bisa dikatakan bahwa kebijakan ini "merupakan produk elite, dan bisa dikatakan merefleksikan nilai-nilai elite untuk penguatan kepentingan-kepentingan mereka. ${ }^{28}$

Selanjutnya, karena Peraturan Presiden Tahun 2012 tentang KKNI ini ditetapkan untuk melaksanakan Peraturan Pemerintah no 32 Tahun 2006 tentang Sistem Pelatihan Kerja Nasional maka model rumusan kebijakan KKNI dalam Peraturan Presiden ini bisa dikelompokkan ke dalam model inkremental, yakni model perumusan kebijakan yang melihat kebijakan publik pada hakikatnya sebagai kelanjutan dari kegiatan-kegiatan yang telah dilakukan oleh pemerintah di masa lampau. Jadi model inkremental kebijakan hanya menghasilkan rumusan

\footnotetext{
24 Wayne Parson, 459.

25 Teori ini mengembangkan diri pada kenyataan bahwa se-demokratis apapun, selalu ada bias dalam formulasi kebijakan karena pada akhirnya kebijakan-kebijakan yang dilahirkan merupakan preferensi politik dari para elite. Riant Nugroho, 400.

26 Dengan demikian pembuatan keputusan yang rasional pada hakikatnya mencakup pemilihan alternatif terbaik yang akan memaksimalkan tingkat kepuasan nilai-nilai pembuatan keputusan-pemilihan alternatif itu dibuat sesudah diadakan analisis yang menyeluruh terhadap alternatif-alternatif yang tersedia dan mempertimbangkan segala akibatnya. Solichin Abdul Wahab, 98.

27 Setiap kebijakan publik yang dibuat pemerintah harus merupakan pilihan publik yang menjadi pengguna. Artinya, proses formulasi kebijakan melibatkan publik melalui kelompok-kelompok kepentingan sehingga model ini bersifat demokratis. Riant Nugroho, 416.

28 Budi Winarno, Kebijakan Publik: Teori, Proses, dan Studi Kasus (Jakarta: Center of Academic Publishing Service, 2007), 45.
} 
kebijakan berupa perubahan-perubahan seperlunya. ${ }^{29}$ Kelemahan kebijakan inkremental ini terlihat dari alasan yang mendasari digunakannya model ini, antara lain pembuat kebijakan tidak memiliki waktu, intelektualitas maupun biaya memadai untuk penelitian terhadap nilai-nilai yang merupakan landasan bagi perumusan kebijakan (lihat Bab 2)." ${ }^{30}$

Berdasarkan proses perumusannya, dapat diketahui bahwa kebijakan KKNI merupakan hasil interaksi di antara institusi-institusi negara, seperti layaknya jenis kebijakan Kontinentalis. Berbeda dengan kebijakan Anglo-saxon yang memahami kebijakan publik sebagai turunan politik demokrasi, dan melihat kebijakan publik sebagai sebuah interaksi antara negara rakyat (publik). ${ }^{31}$ Dengan demikian dapat dipahami bahwa model perumusan kebijakan KKNI yang elitis, inkrementalis ini, tidak sesuai dengan konstitusi negeri ini yang menetapkan Indonesia sebagai negara demokrasi. Mestinya model rumusan pendidikan sebuah negara demokratis seperti Indonesia mengadopsi model kebijakan publik yang demokratis.

Rumusan kebijakan KKNI semestinya mudah dipahami oleh pendidikan tinggi jika perumusannya melibatkan perguruan tinggi, dan sebelum rumusan itu ditetapkan, sosialisasi terhadap rumusan kebijakan KKNI telah dilakukan pada setiap perguruan tinggi dengan alokasi waktu yang memadai, serta memberi kesempatan perguruan tinggi memberikan revisi-revisi untuk dapat diterapkan di perguruan tinggi, karena persoalan pendidikan tinggi yang lebih memahami adalah aktoraktor yang berada di pendidikan tinggi, dan itu sesuai dengan otonomi perguruan tinggi yang juga telah ditetapkan dalam kebijakan pemerintah tentang pengelolaan pendidikan tinggi.

Secara rasional, sulit dipahami bagaimana pemerintah bisa merasa

Solichin Abdul Wahab, Pengantar Analis Kebijakan (Malang: UMM, 2008), 110.

Samodra Wibawa, Kebijakan Publik (Jakarta: Intermedia, 1994), 10.

Riant Nugroho, Public Policy, 22. 
lebih tahu, bahwa solusi terbaik untuk menjadikan perguruan tinggi lebih berkualitas ada pada birokrasi, padahal aktor-aktor di perguruan tinggi-lah sesungguhnya yang lebih paham perihal bagaimana menjadikan perguruan tinggi dapat menghasilkan luaran perguruan tinggi yang berkualitas untuk meningkatkan kualitas sumber daya manusia Indonesia. Itulah sebabnya, Peraturan Pemerintah RI Nomor 4 Tahun 2014 tentang Penyelenggaraan Pendidikan Tinggi dan Pengelolaan Perguruan Tinggi pasal 22 ayat 1 menetapkan, bahwa Perguruan Tinggi memiliki otonomi untuk mengelola sendiri lembaganya sebagai pusat penyelenggaraan Tridharma Perguruan Tinggi. Otonomi pengelolaan perguruan tinggi terdiri dari otonomi di bidang akademik, yakni dalam hal penetapan norma dan kebijakan operasional serta pelaksanaan Tridharma Perguruan Tinggi. Pendidikan, Penelitian, dan Pengabdian Masyarakat. ${ }^{32}$ Berdasarkan Peraturan Pemerintah mengenai otonomi perguruan tinggi tersebut jelaslah, bahwa Peraturan Presiden tentang kebijakan KKNI bertentangan dengan otonomi perguruan tinggi.

Perumusan kebijakan KKNI yang elitis ini kurang memperhatikan bahwa suatu kebijakan yang dipandang baik oleh pemerintah, boleh jadi tidak baik bagi kalangan perguruan tinggi. Keberhasilan kebijakan sesungguhnya terkait erat dengan strategi kebijakan yang tepat, yang mampu mengakomodasi berbagai pandangan serta kepentingan yang beragam. ${ }^{33}$

Isi Peraturan Presiden Tahun 2012 tentang KKNI, hanya memuat hal-hal yang sedikit berbeda dengan ketentuan KKNI dalam Peraturan Pemerintah RI Nomor 31 Tahun 2006 tentang Sistem Kerja Nasional. Perbedaan utamanya hanyalah, jika pada peraturan sistem kerja nasional KKNI ditetapkan sebagai kualifikasi untuk lulusan pelatihan kerja, maka dalam Peraturan Presiden KKNI mencakup kualifikasi kompetensi

\footnotetext{
32 Peraturan Pemerintah RI Nomor 4 Tahun 2014 tentang Penyelenggaraan Pendidikan Tinggi dan Pengelolaan Perguruan Tinggi Pasal 22 ayat 1, 10.

33 Said Zainal Abidin, Kebijakan Publik (Jakarta: Salemba Humanika, 2016), 166.
} 
lulusan untuk semua jenis pendidikan, baik itu pelatihan kerja (pendidikan nonformal), pendidikan formal, dan pendidikan informal. Penetapan KKNI dalam Undang-undang Pendidikan Tinggi Tahun 2012 menciptakan terjadinya tumpang tindih kebijakan KKNI. Kebijakan KKNI dituangkan dalam dua jenis perundang-undangan, di sini terlihat pemerintah ingin memaksakan kehendak yang menurut pemerintah adalah kebijakan terbaik untuk perguruan tinggi dengan alasan demi meningkatkan kualitas sumber daya manusia, sekaligus juga mengabaikan otoritas pendidikan tinggi yang juga telah ditetapkan oleh pemerintah sendiri, ini terbukti dengan kuatnya kontrol pemerintah terhadap kebijakan penerapan KKNI di bidang pendidikan tinggi yang melibatkan lembaga akreditasi.

Persoalan lain yang mengemuka tentang isi kebijakan KKNI adalah perihal kontroversi penggunaan istilah "kompetensi". Pada sistem pelatihan kerja digunakan istilah kompetensi kerja, dan kata kompetensi ini juga digunakan untuk kompetensi lulusan. Berdasarkan buku Panduan Penyusunan Kurikulum yang mengacu pada Permendikti 2015 dikatakan, bahwa, kompetensi kerja, berbeda dengan "kemampuan lulusan", kemampuan lulusan tidak tepat menggunakan kompetensi lulusan, karena kompetensi adalah bagian dari kemampuan lulusan. Penggunaan istilah "kompetensi lulusan" kemudian dimaknai bahwa kompetensi lulusan harus selaras dengan kompetensi kerja, pemaknaan tersebut otomatis melahirkan pandangan bahwa visi, misi institusi pendidikan direduksi hanya untuk menjadi pemasok tenaga kerja. Berdasarkan hal tersebut di atas jelaslah bahwa kebijakan penerapan KKNI belum dikomunikasikan dengan baik oleh pembuat kebijakan kepada pelaksana kebijakan, akibatnya penerapan KKNI di perguruan tinggi tidak sesuai dengan apa yang diharapkan.

Tujuan KKNI untuk meningkatkan kualitas tenaga kerja Indonesia tidak tersosialisasi dengan baik karena terjadinya keragaman pemahaman, sehingga penerapan KKNI tidak mencapai tujuan yang diharapkan. Pemerintah dalam hal ini sepatutnya memahami, informasi 
kebijakan publik perlu disampaikan kepada pelaku kebijakan agar pelaku kebijakan dapat mengetahui, memahami apa yang menjadi isi, tujuan, arah kebijakan agar pelaksana kebijakan dapat melaksanakan kebijakan KKNI, dan agar tujuan dan sasaran kebijakan KKNI untuk meningkatkan kualitas sumber daya manusia Indonesia dapat tercapai. ${ }^{34}$

KKNI sebagai sebuah kebijakan publik pendidikan, sepatutnya bukan hanya melibatkan perguruan tinggi dalam proses perumusan kebijakan tersebut, namun juga pada tahapan sosialisasi rumusan kebijakan tersebut, sebelum diterapkan di perguruan tinggi, agar perguruan tinggi dapat memberikan masukan-masukan penting untuk menghadirkan kebijakan pendidikan yang unggul dan sekaligus dapat diimplementasikan dengan baik.

\section{Kesimpulan}

Kebijakan KKNI yang ditetapkan dalam Peraturan Presiden Republik Indonesia Nomor 8 Tahun 2012 mengacu pada Peraturan Pemerintah Republik Indonesia Nomor 31 Tahun 2006 tentang Sistem Pelatihan Kerja Nasional. Pada kedua perundang-undangan itu, KKNI ditetapkan sebagai acuan dalam penetapan kualifikasi tenaga kerja Indonesia, dan luaran pendidikan tinggi. Acuan yang sama itu diharapkan dapat mengintegrasikan lulusan pelatihan kerja dan luaran pendidikan tinggi. Perbedaan pada kedua perundang-undanagan itu adalah, Peraturan Presiden No 8 Tahun 2012 menetapkan KKNI pada semua jenis pendidikan baik formal, nonformal, dan informal. Sedang dalam Peraturan Pemerintah tentang Sistem Kerja Nasional, KKNI hanya menjadi acuan bagi lulusan pelatihan kerja.

Kebijakan KKNI bidang pendidikan tinggi kemudian juga ditetapkan dalam Undang-undang Pendidikan Tinggi Tahun 2012. Penetapan itu bertujuan untuk mendapatkan landasan yang kuat dari Peraturan Presiden tentang KKNI, karena Peraturan Presiden selayaknya

34 Joko Widodo, 97. 
adalah untuk melaksanakan undang-undang. Dengan dasar itulah maka ketetapan tentang KKNI ditetapkan dalam Undang-undang Pendidikan Tinggi tahun 2012. Setelah Peraturan Presiden tentang KKNI memiliki dasar hukum yang kuat dalam undang-undanng pendidikan tinggi kemudian petunjuk pelaksanaan KKNI yang ditetapkan dalam KKNI ditetapkan dalam Permendikbud 2013 tentang Penerapan Kebijakan KKNI bidang pendidikan tinggi.

Kebijakan KKNI bidang pendidikan tinggi berdasarkan struktur kebijakan menganut model elite, sebuah kebijakan yang mencerminkan kepentingan elite. Model kebijakan ini tidak tepat dalam negara Indonesia yang menganut demokrasi, mestinya kebijkan ini disusun sesuai dengan model pemerintahan demokrasi, yang lebih sesuai adalah model kebijakan pilihan publik, dalam hal ini pilihan perguruan tinggi di Indonesia yang amat beragam, demikian juga dengan stakeholder pendidikan tinggi. Tujuan kebijakan penerapan KKNI sebagai acuan untuk penyetaraan lulusan perguruan tinggi dengan lulusan pelatihan kerja pada pelaksanaannya belum sesuai dengan harapan, karena penetapan KKNI sebagai acuan luaran pendidikan tinggi belum diterapkan pada semua pendidikan tinggi.

\section{Rekomendasi}

Penerapan KKNI di perguruan tinggi direkomendasikan untuk dilanjutkan dengan memaksimalkan komponen-komponen yang mempengaruhi hasil pelaksanaan penerapan KKNI.

Penerapan KKNI telah dilakukan di banyak perguruan tinggi, pemerintah harus terus mensosialisasikan kebijakan tersebut. Bantuan dana yang diberikan oleh pemerintah untuk beberapa perguruan tinggi dalam menyetarakan kurikulumnya dengan KKNI harus terus dilakukan, karena keragaman respon terhadap KKNI lebih disebabkan pada ketidakpahaman tentang KKNI. Perubahan kurikulum tanpa peningkatan kualitas SDM perguruan tinggi, yang terjadi hanyalah perubahan dokumen kurikulum tanpa peningkatan kualitas perguruan 
tinggi dan tamatan perguruan tinggi.

Pendidikan tinggi seharusnya berusaha keras menghadirkan dirinya sebagai pendidikan yang berkualitas, apalagi pendidikan tinggi dijadikan tolok ukur kemajuan sebuah bangsa. Perguruan tinggi harus mampu menghasilkan tamatan dengan kualitas yang tinggi, sesuai dengan kualifikasi KKNI, sehingga tamatannya diterima di dunia kerja. Karena untuk menghadirkan pendidikan tinggi yang berkualitas pemerintah telah menetapkan bahwa kurikulum perguruan tinggi harus disetarakan dengan KKNI, untuk itu perguruan tinggi harus aktif mempelajari kebijakan KKNI yang perumusannya juga telah mengundang perguruan tinggi dalam uji publik. Perguruan tinggi harus memberikan masukan kepada pemerintah sebagai pembuat regulasi tentang hal-hal yang diperlukan untuk penerapan KKNI, karena kurikulum sebuah perguran tinggi tidak pernah stagnan, dan selalu dinamis sesuai dengan perkembangan zaman. 